\title{
Food Poverty in Nigeria: Implications for Life Expectancy
}

\author{
Agu, Anthony $\mathrm{O}$ \\ Department of Economics \\ Chukwuemeka Odumegwu Ojukwu University, Anambra State, Nigeria \\ Agu, Sunday Virtus \\ Department of Economics, Enugu State University of Science and Technology, Nigeria \\ Onwuteaka, Ifeoma C. \\ Chukwuemeka Odumegwu Ojukwu University, Anambra State, Nigeria
}

\begin{abstract}
Food poverty and its effect on life expectancy has over the years attracted greater research attention from many researchers given the attendant negative effects it has on the growth of an economy. This present study investigated the implications of food poverty on life expectancy in Nigeria between 1985 and 2018. It employed the multivariate ordinary least squares, stationarity and cointegration techniques which minimize the possibility of estimating spurious regressions while at the same time, retaining long run information. The independent variables used in the study were total labour force, capital formation, agricultural output (proxy for food poverty) and food items importation. Research findings show that while total labour force, capital formation and food items importation had positive effects on life expectancy in Nigeria, food poverty exerted a negative impact on life expectancy in Nigeria within the period under study. The study recommends, among other things, that the government should through the ministry of agriculture map out policies that will help to further improve the performance of the sector. This will help increase the availability of food items in Nigeria and therefore reduce the incidence of food poverty which will further improve life expectancy in Nigeria.
\end{abstract}

Keywords: food poverty, life expectancy, poverty, food security.

DOI: $10.7176 / \mathrm{JESD} / 11-2-11$

Publication date: January $31^{\text {st }} 2020$

\subsection{Introduction}

Reducing food poverty in developing nations remains a significant public policy challenge, complicated by the absence of an extensive widespread approach to address it. Around 854 million individuals globally are undernourished, many more suffer from deficiencies in micronutrients, and the absolute figures tend to rise further, particularly in sub-Saharan Africa (Mougeot, 2011). Recent inadequacy in food supply and an attendant hike in food prices have helped raise government consciousness of hunger-related issues, leading to fresh global obligations to invest in agriculture in developing nations. While agricultural-led development has played a major part in decreasing food poverty and transforming the economies of many nations in Asia and Latin America, the same has not yet happened in Africa (FAO, 2008).

Food poverty is triggered by the failure of a whole food system, not just manufacturing or a single strand (Ericksen, Ingram, and Liverman, 2009). Thus, food security causes or determinants can be discovered along the entire chain from the total labour force, capital formation, manufacturing, storage, processing, to food distribution. Factors that adversely affect agricultural production such as drought or climate variability, bad soil fertility, and low intake of productivity-enhancing inputs could all adversely affect food security and availability thereby leading to food poverty (Wossen and Berger, 2015). Climate variability is anticipated to continue to decrease rainfall at the start, resulting in a decrease in already low returns in Sub-Saharan Africa (Wossen and Berger, 2015) and exacerbating the already precarious condition of food security. Generally speaking, any attempt to increase output and decrease gaps in agricultural productivity helps to decrease food poverty (Van-Ittersum, 2013).

National, regional and international policy initiatives to decrease or end food insecurity have been intended or even legislated for centuries. For instance, the second agenda of the Sustainable Development Goals is "to end hunger, attain food security and enhance nutrition, and encourage sustainable agriculture" a testament to how crucial the issue is to humanity. Nevertheless, the issue of how to ensure appropriate food and nutrition for the poor and vulnerable in a sustainable way continues to be a challenge for an increasing world population estimated to reach 9.7 billion individuals by 2050 (Wossen and Berger, 2015). In the perspective of its advantages and ability to make a significant contribution to food and nutrition security, revenue generation and poverty alleviation, improvement in agricultural productivity has formed one of the major policy objectives of many countries of the world (Mougeot, 2011)

In addition to making food accessible to families throughout the year if enough is generated, the availability of grain storage equipment helps to decrease the variability in seasonal prices, which is a significant determinant 
of food poverty (Maharjan and Chhetri, 2006); food processing has a comparable effect and thus also contributes to decreasing food poverty (Nwajiuba, 2012). It has been asserted beyond the family that food poverty is more of an issue of allocation of food than of manufacturing (Oriola, 2009). This implies that variables that have an adverse effect on the allocation of food (e.g. bad transport infrastructure) would have an adverse effect on food availability by decreasing access to food and exacerbating food poverty. For instance, high transport costs have been shown to be a significant constraint on food access through its price impact (Kaur and Kaur, 2016). Nigeria's food poverty problem has long been on the front burner (Eme, Onyishi, and Uche, 2014). The nation was faced with horrific pictures of hungry kids-this is particularly worrying for a country that is often considered to be Africa's giant. These pictures portray a catastrophe that can be avoided as the agricultural system in Nigeria is backward and deteriorating over time (Eme et al., 2014). As Oriola (2009) stated, absence of food poverty involves producing food that is going to go around every citizen in terms of quality and amount.

In Nigeria, like other developing countries in Asia and Sub-Saharan Africa, life expectancy has been associated with a wide variety of measures like food poverty, total labour force, heaith, capital formation, food importation etc. Life expectancy is the average mean length of life expected to be lived by an individual at birth (World Health Organization, WHO, 2014). Life expectancy at birth is the breakdown of the death rate that arises across any form of age group in a given year be it young or old.

The improvement of life expectancy to at least 70 years by 2020 is one of Nigeria's health policy targets. Life expectancy is a very crucial measure that affects the developing world striving to achieve socioeconomic progress in health sector, education, sanitation, social safety and environmental management. It is evidenced that in developed countries, life expectancy is relatively high compared to the developing or under developed countries.

The global life expectancy in the year 2015 was in the average mean of 71.4 years, with 73.8 years for the female while 69.1 years for the male. Since 1960, the life expectancy increased by 5 years between 2000 and 2015 , which is said to be the fastest increase (Ogbuabor and Nwosu, 2017). In Nigeria, however, the three deciles averages show that between 1980 and 1989, life expectancy averaged 45.8 years, 1990 and 1999 it was 45.6 while in 2000 and 2010 it improved marginally to an average of 51.1 years. Table 1.1 showed that from 2010 to 2018 , the rate of growth in life expectancy has been in arithmetic progression despite the increases in income and government expenditures on health.

Table 1. Life Expectancy in Nigeria (2000-2018).

\begin{tabular}{|c|c|}
\hline Date & Value \\
\hline 2000 & 50.84 \\
\hline 2011 & 51.27 \\
\hline 2012 & 51.69 \\
\hline 2013 & 52.11 \\
\hline 2014 & 52.54 \\
\hline 2015 & 52.98 \\
\hline 2016 & 53.14 \\
\hline 2017 & 55.91 \\
\hline 2018 & 56.61 \\
\hline
\end{tabular}

Source: Adopted from Etikan, Akinleye and Melitz, 2018.

\subsection{Research issues}

The link between food poverty and life expectancy has continued to attract increasing attention in the research clime. Increased food poverty is usually accompanied by an attendant decline in life expectancy given that food is one of the basic necessities of life, hence, food poverty can lead to malnourishment which culminates into decline in human capital formation and general decline in human productivity thereby affecting the general standard of living and life expectancy in general. The slow development of farming and food production has led to the country's increasing food imports and food poverty.

As Ajayeoba (2010) noted, Nigeria has suffered from food insecurity and poverty as it has been estimated that the amount of hungry individuals in Nigeria exceeds 53 million, which is about $30 \%$ of the country's complete population of approximately 170 million and 52\% live below the poverty line. These are issues of severe interest mainly because in the 1950s and 1960s Nigeria was self-sufficient in food production and in fact a net exporter of food to other countries of the world.

In Nigeria, while agriculture remains a main element of the Nigerian economy, contributing about $41 \%$ of GDP and employing around $70 \%$ of the active population, it gets less than $10 \%$ of annual budget allocations (Orefi, 2012). Consequently, Nigeria's agriculture has failed to provide adequate quantities and quality of food to feed the ever-increasing population (Orefi, 2012). As a result, Nigeria's level of food insecurity and food poverty has been steadily increasing since the 1980s. Food insecurity grew from about $18 \%$ in 1986 to about $41 \%$ in 2004 (Sanusi, Badejo and Yusuf, 2006), with an estimated 170 million people, implying that over 61 million Nigerians 
are food insecure; they are either hungry or undernourished. This is not surprising considering that around $52 \%$ of the inhabitants live below the poverty line (Orefi, 2012).

Food demand in Nigeria has risen quicker than food production in the last century. Most Nigerian farmers are inadequately notified, have insufficient supplies of agricultural inputs, equipment and extension facilities, elevated levels of analphabetism, and absence of sufficient understanding of modern farming methods that can boost production and bumper output to satisfy the ever-increasing food needs and demands of the growing population of Nigeria (Adegbola, Bamishaiye and Daura, 2011). Food crisis is on the rise in Nigeria as most food eaten and traded in Nigeria is cultivated in the country's northern portion. Incessant bombings and other brutal assaults on local economies by both the Boko Haram and Nigerian armed forces present serious hazards to Northern farmers, cattle breeders and farm producers, forcing them to move to new places far from their farmland while putting extra burdens on the transportation of food and farm products to other countries (Eme et al., 2014). The pertinent questions are: To what extent has food poverty influenced life expectancy in Nigeria? What is the causal direction between life expectancy and other macroeconomic variables?

\subsection{Related literature review Conceptual issues}

Food poverty is a state of affairs in which a good number of individuals have no access to secure nutritious food at all times, to preserve a good and active life (Gurkarm, 2005). FAO (1996) also described it as a condition where all individuals have no access to adequate, secure and nutritious food at all times for a healthy and active life. This means availability, accessibility, and adequate use. Food poverty implies inability to ensure that adequate food is accessible, keeping adequate supplies at comparatively stable rates through national manufacturing, enabling access to food for those who need it, and ensuring the biological use of food..

Furthermore, the World Bank (2007) looked at food poverty as poor access to enough food for an active, healthy life by all individuals at all times. Food poverty is therefore not people-oriented and means a condition where all families have no physical and financial access to appropriate food for all employees and families are at a danger of losing such food. There are three elements to food security and food poverty: food availability, food access and food adequacy (Nwaniki, 2007). Food poverty at the national level is seen as the country's supply of inadequate food stocks to satisfy domestic demand until such moment as stocks can be substituted from harvests or imports. It implies at the individual level that all members of society have access to the food they need, either from their own manufacturing, from markets and/or from the transfer system of the government. Also, if at least 2100 kilocalories of energy and 0.75 proteins per kilogram of body weight are accessible per capita per day (Nigeria Food Security Assessment Report, 2003), a nation is regarded nationally food secured. Experiences from several nations have shown that even when food security is attained at domestic level, people and organizations in the nation may still be hungry because they do not have the means to eat (Hossain, Naher and Shubaddin, 2005).

Theoretical underpinnings

\section{The Cobb-Douglas Production Function}

The production function of Cobb-Douglas is commonly used to portray the technological connection between quantities of two or more inputs, especially physical capital and labour, and the quantity of output that these two inputs can produce so that bank credit impacts agricultural output through physical capital finance (Ogbuabor and Nwosu, 2017). The Cobb-Douglas function relates output (Q) to the inputs of capital and labour in a multiplicative function thus:

$\mathbf{Q}=\mathbf{f}(\mathbf{K}, \mathbf{L})=\mathbf{A} \mathbf{K}^{\mathrm{a}} \mathbf{L}^{\mathrm{b}}$

where A, a, and b are all positive constant and Q is the output level; $\mathrm{Q}=$ total production (the monetary value of all goods produced in a year); $\mathrm{L}=$ labour input (the total number of person-hours worked in a year); $\mathrm{K}=$ capital input (the monetary worth of all machinery, equipment, and buildings); $\mathrm{A}=$ total factor productivity/neutral shift factor; $\mathrm{a}$ and $\mathrm{b}$ are the output elasticity of labour and capital respectively. These values as opined by Koutsoyiannis (2002) are constants, determined by available technology. They are also commonly utilized as Cobb-Douglas production function in macroeconomic and microeconomic modelling. The output is measured by either values or quantities.

\section{The Trickle-down theory of development}

The Trickle-down Theory of Development (TTD) is a significant financial theory that connects food safety to growth results. This is a theory of modernization created in 1958 by American economist A.O. Hirschman. This theory is a general economic development model that offers theoretical justification for agricultural investment. Economic development is going to trickle down from the core according to the theory. Hirschman referred jointly to the concentration forces as polarization. The method of spatial concentration of funds into the core was intended by polarization. Polarization, he believes, should be seen as an essential component of the early phases of economic development. He asserted that, by referring to Peroux's (1955) concept of natural growth pole, the corollary of sectoral unbalanced growth is uneven geographical development. 


\section{Empirical Investigation}

Adegbola and Bamishaiye (2011) evaluated government's intervention and the place of effective storage in eliminating food poverty in Nigeria. The study employed exploratory approach to analyse the objectives. The study found out that, there is lack of adequate postharvest practices and this is the main bane of food poverty in Nigeria. The study posits that more should be done to ensure that food is adequately stored after they are produced to nip wastages and scarcity in the bud. Malumfashi and Kwara (2013) examined the effect of agricultural commercialization and food security in Nigeria using OLS regression method. The results show that commercialization enhances food security in the country. Other variables that significantly contribute to food security are domestic food production and food import. Per capita income showed a very weak not significant relationship with food security (Anad, Ravalion and Kabir(1993) who examined 91 developing countries on the same subject.

Igberaese and Okojie (2010) assessed the causes of food poverty in Nigeria and found that food poverty is attributed to bulk buying by the rich, wastage in parties, excessive exports at the expense of domestic needs and the lack of storage facilities leading to post-harvest losses. They recommended that there should be income redistribution, investment in storage facilities and entrenchment of internal order, high limitation on food export and the need to stimulate more food production. Irohibe and Agwu (2014) in an assessment of food security situation among farming households in rural areas of Kano State, Nigeria used a multistage random sampling technique and selected 120 rural farm households for interview. The study analysed the data collected using logistic regression and food security index. The findings reveal that $74 \%$ of the respondents were food secure while $26 \%$ were food insecure. In addition, the study found that the major effect of food insecurity on the households include reduction in household income/ savings due to increased expenditure on food among others.

Gyimah-Brempong and Adesugba (2016) used the general method of moments (GMM) in estimating the relationship between agricultural aid and food security in Africa during the period 1990 to 2012. The findings from the study show at the aggregate level, aid to the agricultural sector has positive and statistically significant effect on food security in African countries. Disaggregating agricultural aid shows that all components of agricultural aid have significant effects on several indices of food security although the strength of the effect varies across indices of food security. Okolo and Obidigbo (2015) examined the level of food availability and accessibility in Nigeria and its implication for life expectancy. The study used multiple linear regression technique and graphic trends of growth rates of relevant variables to show the situation of food security in Nigeria. The findings revealed that population growth rate was higher than the growth rate of food availability in Nigeria. He observed that commercial bank credit to agricultural sector, foreign exchange utilization for food and the Agricultural Credit Guarantee Scheme Fund (ACGSF) contributed significantly to food availability in Nigeria.

.Fankun and Evbuomwam (2017) evaluated agricultural financing, policies, programmes and initiatives for a sustainable development and life expectancy in Nigeria, from 1990-2014. The findings of the study show that Nigerian Government failed to show enough commitments to agricultural activities for its development towards realization of agricultural sustainable development goals.. This is evident in lack of meeting the minimum $10 \%$ and $25 \%$ budgetary allocation to agriculture as stipulated by Maputo declaration and the Food and Agricultural Organization. It was also found out that commercial bank credits to total credit were too low.

Nwankpa (2017) examined the agricultural transformation via-a-vis hunger and poverty eradication as a means of sustaining economic growth and life expectancy in Nigeria. The paper therefore, emphasized significant improvements and effective harnessing of agricultural sector for meaningful and adequate food production and other socio-economic developments through agricultural reforms.

\subsection{Methodology \\ Theoretical framework and empirical model}

The model for this study will be specified using the predictions of the Cobb-Douglas production function which proposes that output is a function of capital and labour inputs. Many economists have studied actual production functions and have used statistical methods to find out relations between changes in physical inputs ad physical outputs. A most familiar empirical production function found out by statistical method is the Cobb-Douglas production function. Originally, Cobb-Douglas production function was applied not to the production process of an individual firm but to the whole of the manufacturing industry. Two factor Cobb-Douglas production function takes the following mathematical form: $\mathbf{Q}=\mathbf{A} \mathbf{L}^{\boldsymbol{\alpha}} \mathbf{K}^{\mathbf{b}}$

Where $\mathrm{Q}$ is the manufacturing output, $\mathrm{L}$ is the quantity of labour employed, $\mathrm{K}$ is the quantity of capital employed and A, $\alpha$ andb are the parameters of the model. Roughly speaking, Cobb-Douglas production function found that about $75 \%$ of the increase in manufacturing production was due to the labour input and the remaining $25 \%$ was due to the capital input. Adopting with modifications the model specified by Malumfashi and Kwara (2013) and using secondary data spanning from 1985 to 2018, the functional form of this model is specified as below:

$\mathrm{LE}=\mathrm{F}(\mathrm{L}, \mathrm{K}, \mathrm{AO}, \mathrm{FI})$ 
The mathematical form of the model is as specified:

$\mathrm{LE}=\alpha+\beta_{1} \mathrm{~L}_{\mathrm{t}}+\beta_{2} \mathrm{~K}_{\mathrm{t}}+\beta_{3} \mathrm{AO}_{\mathrm{t}}+\beta_{4} \mathrm{FI}_{\mathrm{t}}$

Given that there are other variables that affect life expectancy, but for simplicity, these other variables were not explicitly included in the model, the error term will be introduced in the econometric form of the model as specified below to cater for these variables:

$\mathrm{LE}=\alpha+\beta_{1} \log \mathrm{Lt}+\beta_{2} \operatorname{LogKt}+\beta_{3} \log \mathrm{AO}_{\mathrm{t}}+\beta_{4} \operatorname{LogFI} \mathrm{t}_{\mathrm{t}}+\mu_{\mathrm{t}}$

Where:

LE $=$ Life expectancy.

$\log \mathrm{L}=\log$ of total Labour force

$\operatorname{LogK}=\log$ of capital formation

$\log \mathrm{AO}=\mathrm{Log}$ of Agricultural output (proxy for food poverty)

$\operatorname{LogFI}=\log$ of Food items importation

$\alpha=$ Constant $/$ Intercept

$\beta_{1}, \beta_{2}, \beta_{3}$,and $\beta_{4}$ are the parameters.

$\mu=$ Error term.

$\mathrm{T}=$ Time factor.

\subsection{Results and discussion}

\section{Unit Root Test}

Since empirical analysis based on time series data would be biased if the underlying data are non stationary, the unit root test is therefore necessary to check for the stationarity of the variables. The test used for observing the stationarity of the time series data used in this study is the Augmented Dickey-Fuller (ADF) test. The results are summarized on table 2 below.

Table 2 Summary of ADF unit root test result

\begin{tabular}{|c|c|c|c|}
\hline Variables & ADF statistics & Order of Integration & Remarks \\
\hline $\mathrm{D}(\mathrm{AO})$ & -5.436094 & $1(1)$ & Stationary at first difference \\
\hline $\mathrm{D}(\mathrm{FI})$ & -6.865528 & $1(1)$ & Stationary at first difference \\
\hline $\mathrm{D}(\mathrm{K})$ & -5.760613 & $1(1)$ & Stationary at first difference \\
\hline $\mathrm{D}(\mathrm{L})$ & -4.689712 & $1(1)$ & Stationary at first difference \\
\hline $\mathrm{D}(\mathrm{LE})$ & -5.480146 & $1(1)$ & Stationary at first difference \\
\hline
\end{tabular}

Source: Researcher's compilation using Eview 9 (2019).

As seen on table 2, all the variables were stationary at first difference. This provides a strong criterion for the cointegration analysis.

\section{Cointegration Test}

Since short run equilibrium has been revealed to exist among the series, there is the need to investigate the existence or otherwise of long run relationship among these variables. This test will be done using the Johansen cointegraion test. This is necessary because variables that fail to converge in the long run may be hazardous for policy making.

\section{Hypothesis:}

Ho: The variable does not cointegrate

$\mathbf{H}_{1}$ : The variable cointegrates.

Decision Rule

Reject the null hypothesis if the trace statistic $>$ the $5 \%$ critical value or if the probability value $<0.05$. The cointegration test table is presented below:

Table 3. Cointegration result

\begin{tabular}{|c|c|c|c|c|}
\hline Hypothesized No. of CE(s) & Eigen value & Trace statistic & 0.05 critical value & Prob $^{* *}$ \\
\hline None & 0.930396 & 129.2431 & 69.81889 & 0.0000 \\
\hline At most 1* & 0.514539 & 56.63004 & 47.85613 & 0.0049 \\
\hline At most 2* & 0.399237 & 34.22768 & 29.79707 & 0.0110 \\
\hline At most 3 & 0.233480 & 8.431484 & 15.49471 & 0.4205 \\
\hline
\end{tabular}

Source: author's computation using Eviews 9(2019)

From table 3 above, it is evident that there are three cointegrating equations in the series. Hence we reject the null hypothesis and accept the alternative. This, therefore, gives the basis to reject the null hypothesis of no cointegration among the variables at $5 \%$ levels. This confirms the existence of a long run relationship between the short run dynamics and the long run equilibrium of the model. 
Regression Result

Table 4. Summary of the regression result

\begin{tabular}{|c|c|c|c|c|}
\hline Variables & Coefficient & Std. Error & t-statistic & Prob. \\
\hline C & 3.302399 & 47.60121 & 0.069376 & 0.9452 \\
\hline L & 0.017845 & 7.439507 & 0.311559 & 0.7577 \\
\hline K & 0.092813 & 0.966573 & 4.586112 & 0.0001 \\
\hline AO & -0.036992 & 2.180166 & -1.989294 & 0.2365 \\
\hline FI & 0.088690 & 0.415886 & 6.897779 & 0.0000 \\
\hline $\mathrm{R}^{2}=0.741492$ & F stat $=112.6409$ & $\mathrm{R}^{2} \mathrm{Adj}=0.733133$ & Fproby $=0.0000$ & \\
\hline
\end{tabular}

Source: Researcher's compilation using Eview 9(2019)

From table 4 above, the estimated coefficient of 0.017845 for total labour force shows that a percentage increase in total labour force will subsequently increase life expectancy in Nigeria by about $1 \%$. In addition, the estimated coefficient of 0.92813 for capital formation shows that a percentage increase in capital formation will increase life expectancy in Nigeria by about 9\%. Similarly, the coefficient of -0.036992 shows a negative relationship between agricultural output (proxy for food poverty) and life expectancy in Nigeria. This indicates that a percentage increase in food poverty will decrease life expectancy by about $3 \%$. Finally, the coefficient of 0.088690 for food items importation shows that a percentage increase in food items importation will increase life expectancy by about $8 \%$.

\section{Heteroscedasticity Test}

The White general Heteroscedasticity test which follows the chi-square distribution with degree of freedom equals the number of regressors used to test whether the error variances are equal or unequal. The choice of the White test is that it is more standard and general than other tests of heteroscedasticity.

The hypotheses to be tested are:

$H_{0}: \beta_{1}=\beta_{2}=\beta_{3}=\beta_{4}=\beta_{5}=\beta_{6}=0$ (homoscedasticity)

$H_{1}: \beta_{1} \neq \beta_{2} \neq \beta_{3} \neq \beta_{4} \neq \beta_{5} \neq \beta_{6} \neq 0$ (heteroscedasticity)

Decision rule

Reject the null hypothesis if the chi-square calculated is greater than the critical chi-square at $5 \%$ level of significance or the P-value $<0.05$. Accept if otherwise.

The heteroscedasticity table is given below

Table 5. Heteroscedasticity test

\begin{tabular}{|c|c|c|c|c|}
\hline & & & & Decision \\
\hline F statistic & 1.373277 & Probability & 0.2225 & Accept \\
\hline Obs* R-squared & 10.73124 & Probability & 0.2298 & Accept \\
\hline
\end{tabular}

Source: Author's computation (2019)

From table 5 above, it can be observed that the $\mathrm{P}$ value of 0.2225 is $>0.05$. Hence, we accept the null hypothesis and conclude that there is homoscedasticity in the series.

\section{Test for Multicollinearity}

Using the correlation matrix, we test for the existence or otherwise of collinearity among the regressors. It is natural that the regressors in a model be correlated. But conventionally, collinearity above 0.8 indicates a very high collinearity and entails that either of the variables can stand for the other (Gujarati, 2007). The correlation matrix is given as below:

Table 6. Multicollinearity table (correlation matrix)

\begin{tabular}{|c|c|c|c|c|c|}
\hline & LE & L & K & AO & FI \\
\hline LE & 1 & 0.4804626 & 0.3047271 & 0.2097275 & 0.7141777 \\
\hline L & 0.4804626 & 1 & 0.5841832 & 0.5586788 & 0.6245744 \\
\hline K & 0.3047271 & 0.5841832 & 1 & 0.3684602 & 0.4284396 \\
\hline AO & 0.2097275 & 0.5586788 & 0.3684602 & 1 & 0.4866955 \\
\hline FI & 0.7141777 & 0.6245744 & 0.4284396 & 0.4866957 & 1 \\
\hline
\end{tabular}

Source: author's computation using Eviews (2019)

From table 6 above, it is evident that there exist collinearity among the regressors but the coefficients of correlation were not in excess of 0.8 . Hence, this poses no problem for the model.

\section{Discussion of findings}

The research findings showed that there exists a positive and insignificant relationship between total labour force and life expectancy in Nigeria. This implies that increase in total labour force has the tendency of increasing life expectancy given the attendant increase in productivity that accompanies increased labour force. Furthermore, when a growth in total labour force is accompanied by an improvement in the efficiency of labour which is brought about by an improved human capital formation, there will be an attendant increase in the general productivity and manufacturing output; this will invariably increase the amount of goods and services available for consumption 
with an attendant increase in the general demand and disposable income in an economy. This will therefore lead to an improvement in life expectancy.

It was also observed that a positive and significant relationship exists between capital formation and life expectancy. This implies that as capital formation increases, life expectancy is bound to increase owing to the improvement in the productive efficiency which accompanies an increase in capital formation which further increases investment, productivity and improve general welfare, thereby increasing life expectancy. The research findings further showed that a negative and insignificant relationship exists between food poverty and life expectancy in Nigeria. This implies that an increase in food poverty will reduce life expectancy in Nigeria indicating an increase in malnutrition and health challenges that accompany an increase in food poverty. This follows from the fact that malnourishment gives rise to series of diseases and infections which weakens the body system and leads to premature death, thereby reducing the life expectancy of a nation. This finding corroborate with studies like Rodger (1989) that showed a significant tendency for mortality to be lower in countries with a more even distribution of income. Finally, the research findings showed that a positive and significant relationship exists between food items importation and life expectancy in Nigeria. This implies that increase in food items importation would increase life expectancy since more importation of food items will increase the availability of food with an attendant improvement in feeding and general welfare which invariably boosts life expectancy. These findings are in line with those of Fankun and Evbuomwam (2017), and Nwankpa (2017).

\subsection{Conclusion and Policy Recommendations}

Since a positive and insignificant relationship exists between total labour force and life expectancy in Nigeria, the study recommends that efforts should be made by the ministry of labour and productivity in other to improve the productive capacity of the total labour force. This will help improve the general productivity and welfare leading to further significant improvements in life expectancy. Since capital formation was observed to have a positive and significant effect on life expectancy in Nigeria, to foster further significant positive impacts, the study recommends an increased allocation to capital projects. This will help to further improve total capital formation in Nigeria and further lead to increase in life expectancy.Since it was observed that increase in food poverty will decrease life expectancy in Nigeria, the study recommends that the government should through the ministry of agriculture map out policies that will help to further improve the performance of the sector. This will help increase the availability of food items in Nigeria and therefore reduce the incidence of food poverty which will further improve life expectancy in Nigeria.Finally, given the positive relationship existing between food items importation and life expectancy in Nigeria, the study recommends an improvement in the agricultural sector in Nigeria. This will help manage food items importation in Nigeria in other to ensure that the existing positive effect does not lead to imported inflation which will negatively affect life expectancy.

\section{References}

Adegbola, J.A., Bamishaiye, E.I., \& Daura, A.M. (2011). Food security in Nigeria: Government's intervention and the place of effective storage. Asian Journal of Agriculture and Rural Development, 1 (2), 56-63

Adegbola, L.I \& Bamishaiye, M.O. (2011). Measurement and Determinants of food insecurity in Northeast Nigeria: Some empirical policy guidelines. Journal of Food, Agriculture and Environment. 6 (2): 92-96.

Ajayeoba, A. (2010). Concerning Food Security in Nigeria: A West Africa insight of $1^{\text {st }}$ December farming.A Publication of Centre for Democracy and Development, 3- 4

Aliyu,. T. U. (2011).Implication of the Recent Trends and Variability in the Duration of the Growing Season for Food Crop Production in Northern Nigeria, In: Nigerian meteorological societyproceeding of the International conference on climate and sustainable Development, 6th -11 the December, 2009, Osogbo, Nigeria.

Anad, S. \& Ravalion, M. (1993). Human development in poor countries on the role of private income and public services. J econ perspect 133-150 Google scholar

Eme, O.I., Onyishi, .T.,Uche, O.A. \& Uche, I.B. (2014). Challenges of food security in Nigeria: Options before government. Arabian Journal of Business and Management Review, 4 (1), 15 - 25

Fankun, K.O.\& Evbuomwan (2000). Determinant of Food Security in Bauchi Area of Northern Guinea Savanna of Nigeria. (Unpublished Ph.D. Thesis) Department of Agricultural Economics, University of Ibadan.Pp1833.

FAO (2002). The State of Food Insecurity in the World, 2002, Rome. Pp4-10

FAO, (1996). The State of Food and Agriculture. FAO, Rome.

FAO, (2008). The State of Food Insecurity in the World 2008. Food and Agriculture Organization,

Federal Ministry of Agriculture and Rural Development, FMARD (2016).Agricultural Promotion Policy (APP).Abuja, 2016.

Focus 3, Brief 6 of 10, August.IFPRI, Washington, DC.

Food and Agricultural Organization, (2011).Global food losses and waste: Extent, causes and prevention. 


\section{Rome:FAO}

Gujarati, D. N. (2007). Basic econometrics 3. New York McGraw Hill'

Gurkam, R. (2005). Impacts of potential management changes on food security. London:

Gyimah-Brempong, H., \& Adesugba, S.O. (2016).Analysis of food security status of rural households in Doma Area of Nasarawa State, Nigeria.Proceedings of The 23rd Annual National Conference of Farm Management Society of Nigeria. 438-443.

Hossain, M., Naher, F., \& Shahabuddin, Q. (2005). Food security and nutrition in Bangladesh: Progress and determinants. Electronic Journal of Agriculture and Development Economics, 2,(2), 103-135.IFPRI.

Igberaese, V.M. \& Okojie, B.S. (2010).Socio-economic Characteristics and Food Security of Farming Households in Kwara State, North-Central Nigeria.Pakistan Journal of Nutrition. 6: 49-58.

Irohibe, J.M. \& Agwu, E.C. (2001). Encouraging growth to reduce poverty in Nigeria: In C.B.N: Nigerian Economic and Financial Review: 39(2):61-91

Kabir, M. (2008). Determinants of life expectancy in developing countries. J Dev Area 41:185-204.

Maharjan, K. L., \& Chhetri, A. K. (2006).Household food security in rural areas of Nepal: Relationship between socio-economic characteristics and food security status. Paper presented at the International Association of Agricultural Economist conference, Gold coast Australia, August 12-26.

Malumfashi, J.U. \&Kwara, O.F. (2013).Concerning food security in Nigeria.West Africa Insight.http://www.westafricainsight.org/articles/PDF/81 Retrieved on 23/05/2014.

McCalla, A.F. (1999). Prospects for food security in the 21st century: With special emphasis on Africa. Agricultural Economics 20, 95-103 McMillan Publishers.

Mougeot, L.J., 2000. The Hidden Significance of Urban Agriculture.2020 Vision. Nigeria Food Security Assessment Final Report (2003). In fulfilment of contract No. PCE-1-

Nwajiuba C. (2012). Nigeria's food security challenges. Retrieved from www.nestinterative.org

Nwaniki, A. (2007). Achieving food security in Africa: Challenges and issues.Lagos: Longman

Nwankpa, U.M. (2005). Forage Availability and Livestock Management Systems in the Semiarid Zon of North East Nigeria. Ph.D. Thesis, Department of Geography, Bayero University Kano. Pp26-29.

Ogbuabor, J.E. \& Nwosu, C.A. (2017). The impact of deposit money bank's agricultural credit on agricultural productivity in Nigeria: Evidence from an error correction model. International Journal of Economics and Financial Issues, 7 (2), 513-517.

Okolo, P. V.\& Obidigbo, E.M. (2015).Poverty Profile and its Determinants among Farming Households in Borno State. Nigeria. (Unpublished Ph.D. Thesis), University of Maiduguri, Borno State. 142pp.

Okpanachi, U.M. (2004). Policy options for re-positioning the Nigerian agricultural sector. In Ogiji, P. (ed.) The food basket myth: Implications for food security andagricultural reforms in Nigeria. Makurdi: Aboki Publishers

Omotesho, O.A., Adewunmi, M.O., Muhammad-lawal, A. \& Ayinde, O.E. (2006).Determinants of Food Security among the Rural Farming Households in Kwara State, Nigeria. African Journal of General Agriculture.2(1):234-272.

Orefi, A. (2012). Food Security in Nigeria and South Africa: Policies and Challenges. Journal of Human Ecology, $38(1), 31-35$

Oriola, E. O. (2009). Irrigation agriculture.An option for achieving the millennium Development Goals (MDGs) in Nigeria.Journal of Geography and regional planning, 2(7), 176-181.

Peter, I. S. \& Williams C. (2015). Soci-economic determinants of life expectancy (1080-2011). Health economics review. Volume 5:2

Rodger, G. B. (1989). Income and inequality as determinants of mortality; an international cross-sectional analysis. Popul studie 343-351.

Saliu, .H.,Jimoh, .A., \& Arosanyin, .T. (2006). The National question and some selected topical issues on Nigeria. Ibadan: Vantage Publishers

Sanusi, R.A, Badejo, C.A, \& Yusuf, B.O (2006). Measuring household food insecurity in selected local government areas of Lagos and Ibadan, Nigeria.Pak J Nutr, 5, 62-67.

Van Ittersum, M. K., Cassman, K. G., Grassini, P., Wolf, J., Tittonell, P., \& Hochman, Z. (2013). Yield gap analysis with local to global relevance-A review. Field Crops Research, 143, 4-17.

World Bank (2007). World development report 2008, Agriculture for development. Washington D.C: World Bank 